Reprod. Nutr. Dévelop., 1982, 22 (2), 397-403.

\title{
The problem of sexual bipotentiality as exemplified by teleosts
}

\section{R. REINBOTH}

Institut für Zoologie, Johannes-Gutenberg-Universität, D 6500 Mainz, West Germany.

Summary. Most of the work on sex differentiation is devoted to studies on amniotes with particular emphasis on mammals. Our present picture of sex differentiation is formed by the contributions of geneticists, embryologists and endocrinologists. For decades there has been a controversy as to whether sex steroids or (hypothetical) inductor substances play a major role in the process of sex differentiation. The discovery of the $H-Y$ antigen has reanimated this discussion. It is proposed that the use of ambisexual teleost species as unique models of sexual organization in vertebrates might help in further studies to elucidate problems that have never been solved. Among these are : how long can a given germ cell retain its sexual bipotentiality and what are the mechanisms restricting its developmental potency to one sex only.

\section{Introduction.}

To the large majority of scientifically trained biologists sex differentiation among higher (and lower) vertebrates is a well-explored chapter in the vast domain of their discipline. It appears to be firmly established that : 1) fertilization determines the genetic sex of a newly developing specimen, 2) genetic sex is translated consistently into gonadal sex, and 3) gonadal sex has a more or less distinct bearing on the expression of secondary sex characters. This usual subdivision of a very complex developmental pattern has been put forward and ably summarized for amniotes by Price et al. (1975).

In the course of the past few years, new aspects have come to light but some problems that should be answered have remained in oblivion.

Without regretting, as is the fashion, the unavoidable trend to increasing specialization, it is only fair to assert that neither geneticists, developmental physiologists nor endocrinologists have been able to solve on their own some basic problems which still demand a reasonable explanation. In recent times, however, endocrinologists, analyzing hormonal mechanisms that may interact with the process of sexual differentiation, claim to be the closest to the solution of the puzzle. 


\section{The problem of sexual bipotentiality}

The phenotypic expression of gonadal sex is usually linked with the production of either female or male germ cells (oocytes or spermatocytes). If one considers, however, the developmental history of the gonads, it is evident that the somatic elements of the genital organ are the first to appear as reliable indicators of the given sex. It is mere convention to label the germ cells as either "oogonia " or " spermatogonia ". Even electron microscopy has not revealed regular features that enable us to distinguish clearly between the premeiotic germ cells of the sexes, and when some authors provide data for the supposed existence of such distinctive characters, they are compelled to draw at least part of their conclusions from the somatic structure of the tissue in which these germ cells are found (e.g. Bruslé and Bruslé, 1978 a, b). Becarri (1924), who was well aware of the unproved implications of our current terminology, therefore proposed the term " deuterogonia " to designate that generation of germ cells which multiplies by mitotic division before entering meiosis.

The above problem is not only a matter of theorizing; its fundamental relevance becomes apparent in cases where an organism produces sex products opposite to its genetic sex. The questions then arising are : 1) how long can a given germ cell retain its sexual bipotency, 2) can a cell called either a spermatogonium or an oogonium switch its presumed sex, and 3) which factor (or more complex set of influences) causes the irreversible loss of sexual bipotentiality ? To put it succinctly, what induces a premeiotic germ cell to irreversibly enter either oogenesis or spermatogenesis?

This intriguing problem constitutes the main part of the two opposed hypotheses on the mechanisms of sex determination in vertebrates. The so-called " inductor theory " which was advanced and defended by Witschi $(1957,1965)$ has lost ground in favor of the concept that sex steroids control the translation of the genetic to the gonadal sex (Wolff, 1950 ; Jost et al., 1973 ; Neumann et al., 1975). It is hard to understand how Lepori (1980) could assert that " Jost, together with Witschi, is one of the most authoritative supporters of the theory that the sexual differentiation of gonadal primordia is under the control of male and female sex inductors that are different from the steroid sex hormones " (pp. 170-171). Leaving aside minor differences in the interpretation of some details by various investigators, it can be said that the " hormonal theory " deals mainly with the differentiation of the entire genital sytem and does not take much notice of the fate of the ambisexual germ cell or considers it a mere, self-evident consequence of the preceding processes.

The existence of inductor substances, postulated by Witschi, has never been proven, and this lack of evidence is at the root of the present suspicion concerning his hypothesis. But there is not doubt that Witschi's way of reasoning brings the problem of germ cell differentiation into much better focus. It is more than a fortuitous circumstance that Witschi's experimental studies started with amphibians, whereas the advocates of the hormonal theory mentioned above 
worked on mammals and birds. From a comparative point of view, the problem of germ cell differentiation has been given more attention in lower vertebrates (and invertebrates) than in amniotes, due to the larger frequency and variability of many types of ambisexuality in lower vertebrates (Reinboth, 1970, 1975). The experiment by Evans et al. (1977), proving that an XY germ cell may become an oocyte in the mouse, is a commonplace event for researchers working on amphibians, teleosts, crustaceans, annelids or coelenterates.

\section{Ambisexuality in teleosts}

Ambisexual teleosts are probably the most impressive material available for investigating sex development in vertebrates. This is true for the wide range of varieties as well as for the commonness of phenomena which easily compete with the very rare but highly esteemed aberrant features of " normal " gonochorism (e.g. bovine free-martins) attracting the attention of workers on mammals.

It is a pity that an alleged animal peculiarity is handled by most zoologists as an amusing oddness and at the same time as being too far off the "beaten path " for the large majority of research workers who, conditioned by their knowledge and experience of amniotic vertebrates, are fundamentally interested in problems of sex differentiation and determination.

The wide variety of different types of ambisexuality in teleosts is amazing. It ranges from the unique case of the self-fertilizing simultaneous hermaphrodite (Harrington, 1975) to that where two entirely different types of males (primary and secondary) occur in one and the same (protogynous) species (Reinboth, 1970). In a recent paper, Moore (1979) pointed out that a corresponding situation is found in a protandric species with two different types of females.

There are no other vertebrates in which functional sex inversion takes place at the adult stage after one or more spawnings. Finally, it is remarkable that in some sex-inverted species the heterologous germinal tissues are clearly separated from each other at the earliest moment when sex differentiation becomes perceptible, whereas in others the "secondary sex " appears suddenly (de novo or from a sexually predetermined but, until then undiscovered, line of germ cells ?).

Little is known about the developmental history of the gonads of such ambisexual species (D'Ancona, 1949 ; Lissia Frau and Casu, 1968), and we are totally unable to say whether or not morphologically different types of sex inversion (first discernible appearance of the heterologous sex at the adult stage/morphological segregation of the two sexes in the very same gonad a long time before sexual maturation) correspond to physiological dissimilarities in terms of sexual differentiation.

Although I have succeeded in eliciting sex inversion precociously in protogynous species of various types by a single shot of testosterone (Reinboth, 1962, 1975), I do not dare to consider this experimental effect as a model for the events that take place when fishes change sex spontaneously (Reinboth, 1970). In spite of my own data, which are not in evident conflict with Yamamoto's view (1969) on the decisive role sex steroids play in teleost sex differentiation, I am 
reluctant to consider it as a sufficiently proven fact. We simply do not have clear enough criteria to distinguish between what may be either a pharmacological or a physiological effect.

Considering the important research efforts that have been made and are continuing to be made to solve the problems of sex differentiation in mammals, the paucity of corresponding data on teleosts cannot be overlooked. When in recent times the $\mathrm{H}-\mathrm{Y}$ antigen appeared as an entirely new agent during the process of sexual differentiation in mammals (Wachtel et al., 1975; Ohno et al., 1979), it could not be excluded that a similar non-steroidal factor might be involved in either sex differentiation or sex inversion of lower vertebrates. Recent papers point to a rather widespread occurrence of the $\mathrm{H}-\mathrm{Y}$ antigen in vertebrates (Müller and Wolf, 1979 ; Pechan et al., 1979 ; Müller et al., 1979 ; Engel and Schmid, 1981 ; Zaborski, 1981). It would be premature to speculate on the eventual significance of some kind of $\mathrm{H}-\mathrm{Y}$ antigen in (ambisexual) teleosts. But in conjunction with our own findings described above, recent studies on mammals merit particular attention since they demonstrate that the effectiveness of the sex-specific $\mathrm{H}-\mathrm{Y}$ antigen may extend beyond the embryonic stage of gonadogenesis (Zenzes et al., 1978 ; Iwata et al., 1979 ; Winters et al., 1979).

From a morphological point of view, it is easier to understand why teleosts are the only vertebrates in which spontaneous sex-inversion occurs in adult specimens. The entire genital apparatus, as compared to that in other classes, usually has a relatively simple structure which is not connected to the excretory system in either sex ; no major transformations are required to change an ovary into a testis or viceversa. In protogynous species the was deferens of the future male is either preformed very early or develops from crevices in the ovarian wall (Reinboth, 1962). In the protandric Amphiprion, the future ovarian cavity is already present in the caudal part of the (ambisexual) testis (Reinboth, 1980).

The known dualistic origin of the tetrapod gonad from the cortex and the medulla does not apply to teleosts. This led D'Ancona (1949) to replace Witschi's hypothetical inductor substances (corticin and medullarin) by corresponding compounds which he named " gynogenin " and " androgenin ". But D'Ancona's reasoning did not find much response, probably due to obvious conflicts between his hypothesis and the mere facts of its basis. Moreover, D'Ancona partly misinterpreted Witschi. Whereas Witschi always understood the proposed inductors in the true sense of the word, as principles controlling sexual differentiation, D'Ancona described them in teleosts as promoting the full development of previously differentiated sexual tissues (Reinboth, 1962).

Witschi in one of his last publications (1967) extended his concept by introducing antagonistic principles which he called " medullary " and " cortical antagonists ", and added : "Since each antagonist inhibits or even destroys the opposite inductor system, their activities resemble immune reactions " (p. 208). This latter remark relates Witschi's conventional ideas closely to the $H-Y$ antigen as an agent inducing gonadal differentiation (in mammals) in connection with a gonad-specific $\mathrm{H}-\mathrm{Y}$ antigen receptor and a postulated ovarian factor. The interaction between these principles is a matter of dispute and current research. 
Two recent papers from Wolf's group illustrate the actual state of affairs (Zenzes et al., 1980 ; Müller and Urban, 1981).

During the last two decades, zoologists finally became aware that functional ambisexuality is a common phenomenon in teleosts. Most investigators emphasized a totally different aspect of the phenomenon. They tried to determine the " biological advantages " of being non-gonochoristic, thus instigating many ecological and behavioral studies (Warner et al., 1975). Others skipped these difficult puzzles and tried to immediately determine the kind of mechanism causing an adult animal to successfully change its sex. Among the environmental stimuli used to explain this, the idea of a " social control " of sex inversion has gained the greatest popularity. Aside from the fact that the evidence for this hypothesis is scanty at the moment, its most serious deficiency is that the events happening inside the animal when a gonad changes its sexual role are being totally neglected (Reinboth, 1980).

\section{Conclusions.}

The problem of sex determination and differentiation is a classical chapter of general biology. After the discovery of the heredity of sex, key words like " genotypical " and " phenotypical " sex determination were mainly used in that field for a long time (Bacci, 1965). Increasing knowledge of the tremendous variability of the genetic constitutions involved in the realization of the teleost sexes has contributed to a more modest judgement of the importance of genetic arguments for answering the questions that are raised here (Quillier, 1981).

The development of comparative endocrinology and the availability of sex hormones for experimental purposes paved the way for the " hormonal theory " of sex determination. Recent findings on the role of $\mathrm{H}-\mathrm{Y}$ antigen for gonad differentiation have led us further away from the belief that genetic information is directly translated into the production of sex steroids. The conspicuous phenomenon of many types of ambisexuality in teleosts raises the old problem of sexual bipotency and supplies new questions for all researchers working on sex differentiation.

Communication présentée au colloque sur la "Sexualisation chez les Vertébrés inférieurs", Banyu/s-sur-Mer, France, avril 1981.

Reçu en mai 1981.

Accepté en septembre 1981.

Résumé. Les recherches sur la différenciation sexuelle sont pour la plupart consacrées aux amniotes et notamment aux mammifères.

Notre conception de la différenciation sexuelle est le fruit des travaux des généticiens, des embryologistes et des endocrinologistes. Depuis des décennies, il n'a pas été possible de trancher pour savoir si la différenciation sexuelle doit être attribuée fondamentalement aux stéroïdes sexuels ou à l'hypothétique substance inductrice.

La découverte de l'antigène $\mathrm{H}-\mathrm{Y}$ a fait rebondir ce problème classique. Nous suggérons que le recours au modèle constitué par les Téléostéens ambisexuels devrait permettre de 
résoudre des problèmus qui n'ont jusqu'ici jamais été résolus. Parmi ceux-ci, il faut retenir que l'on continue à ignorer pendant combien de temps une cellule germinale donnée peut conserver sa bipotentialité sexuelle et par quels mécanismes restrictifs ses potentialités de développement peuvent être dirigées dans le sens d'un sexe unique.

\section{References}

BACCI G., 1965. Sex determination, Pergamon Press, 306 pp.

BECCARI N., 1924. Studi sulla prima origine delle cellule genitali nei vertebrati. III. Ricerche nel Bufo viridis. Arch. ital. Anat. Embr., 21, 332-374.

BRUSLÉ S., BRUSLÉ J., 1978 a. Early sex differentiation in Mugil (Liza) auratus Risso, 1810 (Teleost Mugilidae). An ultrastructural study. Ann. Biol. anim. Bioch. Biophys., 18, 871-875.

BRUSLÉ S., BRUSLÉ J., 1978 b. An ultrastructural study of early germ cells in Mugil (Liza) auratus Risso, 1810 (Teleostei : Mugilidae). Ann. Biol. anim. Bioch. Biophys., 18, 1141-1153.

D'ANCONA U., 1949. Ermafroditismo ed intersessualità nei Teleostei. Experientia, V, 381-389.

ENGEL W., SCHMID M., 1981. H-Y Antigen as a Tool for the Determination of the Heterogametic Sex in Amphibia. Cytog. Cell Genet. (in press).

EVANS E. P., FORD C. E., LYON M. F., 1977. Direct evidence of the capacity of the XY germ cell in the mouse to become an oocyte. Nature (Lond.), 267, 430.

HARRINGTON R. W., Jr., 1975. Sex Determination and Differentiation among Uniparental Homozygotes of the Hermaphroditic Fish Rivulus marmoratus (Cyprinodontidae: Atheriniformes), 249-262. In REINBOTH R. Intersexuality in the animal kingdom, SpringerVerlag, Berlin Heidelberg New York.

IWATA H., NAGAI Y., STAPLETON D. D., SMITH R. C., OHNO S., 1979. Identification of human $\mathrm{H}-\mathrm{Y}$-antigen and its testis-organizing function. Arthritis Rheum., 22, 1211-1216.

JOST A., VIGIER B., PREPIN J., PERCHELLET J. P., 1973. Studies on sex differentiation in mammals. Rec. Progr. Horm. Res., 29, 1-41.

LEPORI N. G., 1980. Sex differentiation, hermaphroditism and intersexuality in vertebrates including man. Piccin Medical Books, Padua, $345 \mathrm{pp}$.

LISSIA FRAU A. M., CASU S., 1968. II processo gonadogenetico in alcune specie di Sparidi (Teleostei, Perciformes). Studi Sassaresi, 46, 50-72.

MOORE R., 1979. Natural sex inversion in the giant perch (Lates calcarifer). Aust. J. Mar. Freshwater Res., 30, 803-813.

MÜLLER U., URBAN E., 1981. Reaggregation of rat gonadal cells in vitro: experiments on the function of $\mathrm{H}-\mathrm{Y}$ antigen. Cytog. Cell Genet. (in press).

MÜLLER U., WOLF U., 1979. Cross-reactivity to mammalian anti-H-Y antiserum in teleostean fish. Differentiation, 14, 185-187.

MÜLLER U., ZENZES M. T., WOLF U., ENGEL W., WENIGER J. P., 1979. Appearance of H-W $(\mathrm{H}-\mathrm{Y})$ antigen in the gonads of cestradiol sex-reversed male chicken embryos. Nature (Lond.), 280, 142-144.

NEUMANN F., ELGER W., STEINBECK H., GRÄF K.-J., 1975. The role of androgens in sexual differentiation of mammals, 407-421. In REINBOTH R., Intersexuality in the animal kingdom, Springer-Verlag, Berlin Heidelberg New York.

OHNO S., NAGAI Y., CICCARESE S., IWATA H., 1979. Testis organizing $\mathrm{H}-\mathrm{Y}$ antigen and the primary sex determining mechanism of mammals. Rec. Progr. Horm. Res., 35, 449-476.

PECHAN P., WACHTEL S. S., REINBOTH R., 1979. H-Y antigen in the teleost. Differentiation, 14, 189-192.

PRICE D., ZAAIJER J. J. P., ORTIZ E., BRINKMANN A. O., 1975. Current views on embryonic sex differentiation in reptiles, birds and mammals. Amer. Zool., 15 (Suppl. 1), 173195.

QUILLIER R., 1981. Communication présentée au Colloque Sexualisation chez les Vertébrés inférieurs, Banuyls-sur-Mer.

REINBOTH R., 1962. Morphologische und funktionelle Zweigeschlechtlichkeit bei marinen Teleostiern (Serranidae, Sparidae, Centracanthidae, Labridae). Zool. Jb. (Physiol.), 69, 405-480.

REINBOTH R., 1970. Intersexuality in fishes. Mem. Soc. Endocrinol., 18, 515-543.

REINBOTH R., 1975. Spontaneous and hormone-induced sex-inversion in wrasses (Labridae). Pubbl. Staz. Zool. Napoli, 39 Suppl., 550-573.

REINBOTH R., 1980. Can sex inversion be environmentally induced? Biol. Reprod., 22 49-59. 
WACHTEL S. S., OHNO S., KOO G. C., BOYSE E. A., 1975. Possible role of H-Y antigen in the primary determination of sex. Nature (Lond.), 254, 270-272.

WARNER R. R., ROBERTSON D. R., LEIGH E. G., Jr., 1975. Sex change and sexual selection. Science, 190, 633-638.

WINTERS S. J., WACHTEL S. S., WHITE B. J., KOO G. C., JAVADPOUR N., LORIAUX L., SHERINS R. J., 1979. H-Y antigen mosaicism in the gonad of a $46, \mathrm{XX}$ true hermaphrodite. N. Engl. J. Med., 300, 745-749.

WITSCHI E., 1957. The inductor theory of sex differentiation. J. Fac. Sci. Hokkaido Univ., $13,428-439$.

WITSCHI E., 1965. Hormones and embryonic induction. Arch. Anat. micr. Morph. exp., 54, 601-611.

WITSCHI E., 1967. Biochemistry of sex differentiation in vertebrate embryos, 193-223. In WEBER R., The biochemistry of animal development. Vol. II. Biochemical control mechanisms and adaptations in development, Acad. Press, New York, London.

WOLFF Et., 1950. Le rôle des hormones embryonnaires dans la différenciation sexuelle des Oiseaux. Arch. Anat. micr. Morph. exp., 39, 426-450.

YAMAMOTO T., 1969. Sex differentiation, 117-175. In HOAR W. S., RANDALL. D., Fish physiologv, III, Acad. Press, New York.

ZABORSKI P., 1981. Communication présentée au Colloque Sexualisation chez les Vertébrés inférieurs, Banyuls-sur-Mer.

ZENZES M. T., WOLF U., GUNTHER E., 1978. Studies on the function of H-Y antigen. Dissociation and reorganization experiments of rat gonadal cells. Cytogenet. Cell Genet., 20, 365.

ZENZES M. T., URBAN E., WOLF U., 1980. Inhibition of testicular organization in vitro by newborn rat ovarian cell supernatants. Differentiation, 16, 193-198. 